\title{
Effect of Two Stimulating Substances on Fruiting and Fruit Quality of Picual and Manzanillo Olive Cultivars.
}

\author{
Emad Girgis Mikhail and Kamal Girgis Goargiuos \\ Olive and Semi arid Zone Fruits Dept. \\ Horticulture Research Institute, Agriculture Research Center, Giza
}

This study was carried out through 2012 and 2013 seasons to study the effect of mono-potassium phosphate (MKP) $0.3 \%$ and Hokley alpha (naphthalene acetic acid (NAA 0.45\%) + naphthalene acetamide (NAD 1.2\%) as foliar application on fruiting and fruit quality of "Picual" and "Manzanillo" Picual and Manzanillo olive cvs. planted in a private farm in an orchard 9 years pld at Cairo Alexandria Desert Road planted at 4X 6 meters apart. Most tested treatments revealed positive effects and improved fruit set, yield, fruit characters and fruit oil content. Moreover, the tested treatments reduced the number of dropped fruits and improved fruit retained. The most effective treatment was the spray of MKP at $1^{\text {st }}$ February + Hokley alpha (NAA + NAD) before flowering then at $40 \%$ flowering through enhancing tree yield and oil content, moreover besides reducing alternate bearing.

Key words: olive "Picual", "Manzanillo" fruit set, yield, oil content, NAA, MKP.

\section{Introduction}

Olive (Olea europaea L.) belongs to family Oleaceae, is one of the most important fruit crop grown worldwide due to its nutritional and economical importance. Unfruitfulness in olive has frequently been observed which may be attributed to numerous factors. Some of them are probably related to the internal imbalance of growth regulators and other physiological factors (Taghipour et al., 2011 and Birger et al., 2008). Biennial bearing is a major horticultural and economical drawback of olive cultivation, which particularly affects the olive oil industry (Dag et al., 2009). Using naphthalene acetic acid (NAA) shortly after full bloom is commonly practiced to increase olive fruit thinning but increase fruit size (Birger et al., 2008; Dag et al., 2009; Qureshi et al., 2012 and Barone et al., 2014). Nitrogen, phosphorus and potassium are major elements found in large quatities in different tree organs. Abdolla et al, (1986) showed that P levels in the ovary are at their maximum value just prior to full bloom and are reduced by $62 \%$ after the transformation of the flower to a fruitlet. Bar Akiwa et $\boldsymbol{a l}$, (1988) reported that when $\mathrm{P}$ is supplied to grape vine increased yield and improved fruit quality. However, Sibbett and Ferguson (2002) observed that, Manzanillo olive trees at "On" season contained higher $\mathrm{N}$ and $\mathrm{K}$ or B elements than at "Off" season specially as fruits began the maturation process (mid-September and October).

Moreover, many reports stated that monopotassium phosphate (MKP) was superior to improve nutritional status (Sarrwy et al., 2010), as a fast source of $\mathrm{P}$ and $\mathrm{K}$ when applied as a foliar spray (Arquero et al., 2002 and Barranco et al., 2010). Also, MKP spray improved olive flowering, fruit set, yield and oil quality with earlier harvesting dates (Toscano and Casacchia, 2006).

Furthermore Maltoni, (1992) Honeyboren (1993) and Gomand and Gossens (2010) mentioned that, naphthalene acetamide (NAD) reduced fruit set as well as reduced fruit yield of apple. Comai and Dorigoni (1998), Gomand and Gossens (2010) on apple and Taghipour et al., (2011) on apricot showed that NAD spray increased fruit thinning, fruit weight and volume as well as fruit $\mathrm{L} / \mathrm{D}$ ratio (Rahemi and Atahosseini, 2004 on pomegranate and Taghipour et al., 2011 on apricot).

The present study aimed to determine the impact of spraying mono-potassium phosphate at February, $1^{\text {st }}$ alone or combined with Hokly Alpha (naphthalene acetic acid $0.45 \%+$ naphthalene acetamide $1.2 \%$ ) at ${ }^{\mathrm{t}}$ February, $1^{\mathrm{s}}$ and/or at $40 \%$ flowering on fruit set, fruit thinning and yield fruit characteristics of Picual and Manzanillo olive trees.

\section{Material and Methods}

The present study was carried out during 2012 and 2013 growing seasons on 9 years old "Picual" and "Manzanillo" olive trees, planted in a private farm at 90 Kilometer from Cairo (Cairo Alexandria Desert Road). Trees were uniform in shape and size as possible and planted $6 \times 4$ meters apart on sandy loam soil and irrigated with drip irrigation system from well (underground water). Trees were selected for this study received the normal organic and chemical fertilizers in winter at the beginning of November, and the chemical fertilization program during the growing season. Also, irrigation and pest control program executed according to (Elsayed and Saad El-Din, 2011).

This study is considered a factorial experiment as it included two factors as follows: 


\section{1- Olive cultivar.}

Two olive cultivars namely, Picual and Manzanillo were subjected to this study.

\section{2- Cultural treatments.}

The two tested olive cultivars (Picual and Manzanillo) were treated in both seasons with one of the following treatments:-

a) Control "Tap water" Picual and Manzanillo olive trees were foliar sprayed with tap water as a control treatment.

b) Mono potassium phosphate (MKP) foliar spray at $0.3 \%$ on February, $1^{\text {st }}$.

c) MKP foliar spray at $0.3 \%$ on February, $1^{\text {st }}$ provided with Naphthalene acetic acid $(0.45 \%)$ and Naphthalene acetamide (1.2\%) (Hokley alpha) before blooming.

d) MKP foliar spray at $0.3 \%$ on Feb. $1^{\text {st }}$ supported with Hokley alpha at $40 \%$ blooming.

e) MKP foliar spray at $0.3 \%$ on Feb. $1^{\text {st }}$ supplemented with Hokley alpha just before blooming and repeated at $40 \%$ blooming.

Furthermore, the control trees were sprayed with tap water and tween 20 was added at $0.1 \%$ as a surfactant to all spray solutions including the control "tap water". Spraying process was carried out using a compression sprays (5 L. solution/tree).

Generally, this experiment is considered a factorial experiment $(2$ cultivar $\mathrm{x}$ cultural treatments). The treatments were arranged in a completely randomized design with three replicates for each treatment and each replicate was represented by one tree.

The response of Picual and Manzanillo trees to the tested treatments was evaluated through the following measurements.

\section{I- Fruiting.}

a- Number of fruitlets at the beginning of May, and number of fruits in mid-June and before harvesting at the beginning of September were calculated per meter.

b- Yield: Average yield (Kg/tree) was calculated for each treatment.

c- Fruit quality: Thirty fruits per each treated tree were randomly picked for carrying out the fruit quality measurements: Fruit length $(\mathrm{cm})$, fruit diameter $(\mathrm{cm})$, fruit shape index (length/diameter), fruit weight $(\mathrm{g})$, flesh/fruit weight, seed length $(\mathrm{cm})$, seed diameter $(\mathrm{cm})$ and seed weight $(\mathrm{g})$.

d- Biennial bearing index: Biennial bearing index of the different treated trees was calculated according to Wilcox (1944) as follows:

Biennial bearing index $=$

Differences in yield $(\mathrm{kg})$ between successive years x100

Sum of yield $(\mathrm{kg})$ of successive years
II- Oil percentage as dry weight, was determined means of Soxhalt extraction apparatus using petroleum ether at $60-80^{\circ}$ boiling point as described by A.O.A. C. (1990)

\section{Statistical analysis:}

The obtained data were subjected to analysis of variance (ANOVA) according to Snedecor and Cochran (1980). Differences between treatments were compared by Duncan's multiple range test (Duncan, 1955).

\section{Results}

\section{1- Tree fruiting.}

Table, (1) shows the effect of monopotassium phosphate $(0.3 \%)$ (MKP) and Naphthalene acetic acid and Naphthalene acetamide (Hokly alpha) on fruit characteristics during 2012 and 2013 seasons. It is obvious that Manzanillo olive trees surpassed Picual in fruit set $\%$, fruit set $/ \mathrm{m}$ and retained fruit $/ \mathrm{m}$ in both seasons. On the other hand, Picual cv. illustrated the highest drop percentage moreover all combinations of Manzanillo and Picual cvs.

Moreover, foliar tested application of MKP in $1^{\text {st }}$ of February and Hokly alpha before flowering provided with $40 \%$ flowering application on Picual and manzanillo gave the highest significant values of fruit set $\%$, fruit set $/ \mathrm{m}$ and retained fruit/m compared with the control and other treatments ascendingly during 2012 and 2013 seasons. However, for the fruit drop percentage/m the control showed the highest significant value compared to the other treatments in both seasons.

Concerning the combinations of Manzanillo and Picual cvs. treated with MKP and Hokly alpha foliar applications. Manzanillo cv. treated with foliar spray of MKP 0.3 in the $1^{\text {st }}$ of February and Hokly alpha before lowering in addition to during $40 \%$ flowering showed the superior values compared with the Picual, the other treatments and the control. Manzanillo, other tested combinations showed an intermediate significant value in this concern.

The effect of monopotassium phosphate (MKP) and Naphthalene acetic acid and Naphthalene acetamide (Hokly alpha) on Picual and Manzanillo yield during 2012 and 2013 seasons are illustrated in Table (2). 
Table 1. Effect of mono potassium phosphate and Hokleyalpha on fruit set, fruit drop percentage and retained fruit of "Picual and Manzanillo" olive trees during 2012 and 2013 seasons.

\begin{tabular}{|c|c|c|c|c|c|c|c|c|c|c|c|c|}
\hline \multirow[b]{2}{*}{ Cultivars } & \multicolumn{3}{|c|}{ Fruit set $(\%)$} & \multicolumn{3}{|c|}{ Fruit set $/ \mathrm{m}$} & \multicolumn{3}{|c|}{ Fruit drop percentage/m } & \multicolumn{3}{|c|}{ Retained fruit $/ \mathrm{m}$} \\
\hline & Picual & Manzanillo & Mean & Picual & Manzanillo & Mean & Picual & Manzanillo & Mean & Picual & Manzanillo & Mean \\
\hline \multicolumn{13}{|c|}{ First season 2012} \\
\hline Control & $2.93 f$ & $5.77 \mathrm{Cd}$ & $4.35 \mathrm{C}$ & $11.85 \mathrm{~d}$ & $19.87 \mathrm{c}$ & $15.86 \mathrm{D}$ & $24.95 \mathrm{a}$ & $11.65 \mathrm{~cd}$ & $18.30 \mathrm{~A}$ & $2.20 \mathrm{e}$ & $5.10 \mathrm{c}$ & $3.65 \mathrm{C}$ \\
\hline $\begin{array}{l}\text { Foliar spray of mono-potassium phosphate } \\
\qquad 0.3 \% \text { in } 1 \text { st February }\end{array}$ & $3.03 \mathrm{f}$ & $5.90 b-d$ & $4.47 \mathrm{C}$ & $12.19 \mathrm{~d}$ & $24.00 \mathrm{~b}$ & $18.09 \mathrm{C}$ & $19.48 b$ & 10.79de & 15.14B & $2.43 \mathrm{e}$ & $5.27 \mathrm{c}$ & $3.85 \mathrm{C}$ \\
\hline $\begin{array}{c}\text { Foliar spray of mono-potassium phosphate } \\
0.3 \% \text { in } 1 \text { st February and hokley alpha } \\
\text { before flowering }\end{array}$ & $5.43 \mathrm{de}$ & $6.43 \mathrm{~B}$ & $5.93 \mathrm{~B}$ & $20.99 \mathrm{c}$ & $23.42 b$ & $22.21 \mathrm{~B}$ & $14.01 \mathrm{c}$ & $8.20 \mathrm{ef}$ & $11.11 \mathrm{C}$ & $4.67 d$ & $5.90 \mathrm{~b}$ & $5.28 \mathrm{~B}$ \\
\hline $\begin{array}{l}\text { Foliar spray of mono-potassium phospate } \\
0.3 \% \text { in } 1 \text { st February and hokley alpha at } \\
40 \% \text { flowering }\end{array}$ & $5.20 \mathrm{e}$ & $6.43 \mathrm{~B}$ & $5.82 \mathrm{~B}$ & $20.01 \mathrm{c}$ & $23.06 \mathrm{~b}$ & $21.53 \mathrm{~B}$ & $14.02 \mathrm{c}$ & $6.06 \mathrm{f}$ & $10.04 \mathrm{C}$ & $4.47 \mathrm{~d}$ & $6.03 b$ & $5.25 \mathrm{~B}$ \\
\hline $\begin{array}{c}\text { Foliar spray of mono-potassium phosphate } \\
0.3 \% \text { in } 1 \text { st February and hokley alpha } \\
\text { before flowering }+40 \% \text { flowering }\end{array}$ & $6.07 \mathrm{bc}$ & 7.77A & $6.92 \mathrm{~A}$ & $23.26 \mathrm{~b}$ & $27.61 \mathrm{~A}$ & $25.44 \mathrm{~A}$ & $12.63 \mathrm{~cd}$ & $8.16 \mathrm{ef}$ & $10.39 \mathrm{C}$ & $5.30 \mathrm{c}$ & $7.13 \mathrm{~A}$ & $6.22 \mathrm{~A}$ \\
\hline Mean & $4.53 \mathrm{~B}$ & $6.46 \mathrm{~A}$ & & 17.66B & $23.59 \mathrm{~A}$ & & $17.02 \mathrm{~A}$ & $8.97 b$ & & $3.81 \mathrm{~B}$ & $5.89 \mathrm{~A}$ & \\
\hline \multicolumn{13}{|c|}{ Second season 2013} \\
\hline Control & $2.43 \mathrm{e}$ & $3.70 \mathrm{~d}$ & $3.07 \mathrm{E}$ & $9.72 \mathrm{~h}$ & $12.52 \mathrm{f}$ & $11.12 \mathrm{D}$ & $28.91 \mathrm{a}$ & $21.57 \mathrm{c}$ & $25.24 \mathrm{~A}$ & $1.73 \mathrm{~g}$ & $2.90 \mathrm{e}$ & $2.32 \mathrm{E}$ \\
\hline $\begin{array}{l}\text { Foliar spray of mono-potassium phosphate } \\
0.3 \% \text { in } 1 \text { st February }\end{array}$ & $2.70 \mathrm{e}$ & $3.83 \mathrm{~d}$ & $3.27 \mathrm{D}$ & $10.92 \mathrm{~g}$ & $12.90 \mathrm{f}$ & 11.91D & $15.31 \mathrm{e}$ & $19.19 \mathrm{~d}$ & $17.25 \mathrm{C}$ & $2.30 \mathrm{f}$ & 3.10de & $2.70 \mathrm{D}$ \\
\hline $\begin{array}{l}\text { Foliar spray of mono-potassium } \\
\text { phosphate } 0.0 .3 \% \text { in } 1 \text { st February and } \\
\text { hokley alpha before flowering }\end{array}$ & $3.67 \mathrm{~d}$ & $4.33 \mathrm{c}$ & $4.00 \mathrm{C}$ & $14.30 \mathrm{e}$ & $15.00 \mathrm{c}$ & $14.65 \mathrm{C}$ & $21.84 \mathrm{c}$ & $17.60 \mathrm{~d}$ & $19.72 \mathrm{~B}$ & $2.87 \mathrm{e}$ & $3.57 \mathrm{c}$ & $3.22 \mathrm{C}$ \\
\hline $\begin{array}{l}\text { Foliar spray of mono-potassium phospate } 0 . \\
0.3 \% \text { in } 1 \text { st February and hokley alpha at } \\
40 \% \text { flowering }\end{array}$ & $4.20 \mathrm{c}$ & $4.90 \mathrm{~b}$ & $4.55 \mathrm{~B}$ & $16.02 \mathrm{~cd}$ & $17.02 b c$ & $16.52 \mathrm{~B}$ & $25.31 \mathrm{~b}$ & $15.68 \mathrm{e}$ & $20.50 \mathrm{~B}$ & $3.13 \mathrm{ab}$ & $4.13 b$ & $3.63 \mathrm{~B}$ \\
\hline $\begin{array}{l}\text { Foliar spray of mono-potassium } \\
\text { phosphate } 0.0 .3 \% \text { in } 1 \text { st February and } \\
\text { hokley alpha before flowering }+40 \% \\
\text { flowering }\end{array}$ & $4.73 b$ & $5.87 \mathrm{~A}$ & $5.30 \mathrm{~A}$ & $18.09 \mathrm{~b}$ & $19.93 \mathrm{~A}$ & $19.01 \mathrm{~A}$ & $27.45 a$ & $11.87 \mathrm{f}$ & 19.66B & $3.43 a$ & $5.17 \mathrm{~A}$ & $4.30 \mathrm{~A}$ \\
\hline Mean & $3.55 \mathrm{~B}$ & $4.83 \mathrm{~A}$ & & $13.81 \mathrm{~B}$ & $15.47 \mathrm{~A}$ & & $23.77 \mathrm{~A}$ & 17.18B & & $2.69 \mathrm{~B}$ & $3.77 \mathrm{~A}$ & \\
\hline
\end{tabular}

Means within each column or raw followed by the same letter (s) are not significantly different at $5 \%$ level. 
Table 2. Effect of mono potassium phosphate and Hokleyalpha on yield and biennial bearing index (2013) of "Picual and Manzanillo" olive trees during 2012 and 2013 seasons.

\begin{tabular}{|c|c|c|c|c|c|c|c|c|c|}
\hline \multirow{4}{*}{ Cultivars } & \multicolumn{6}{|c|}{ Yield (kg/tree) } & \multirow{2}{*}{\multicolumn{3}{|c|}{ Biennial bearing index }} \\
\hline & \multicolumn{3}{|c|}{ First season 2012} & \multicolumn{3}{|c|}{ Second season 2013} & & & \\
\hline & \multirow{2}{*}{ Picual } & \multirow{2}{*}{ Manzanillo } & \multirow{2}{*}{ Mean } & \multirow{2}{*}{ Picual } & \multirow{2}{*}{ Manzanillo } & \multirow{2}{*}{ Mean } & \multirow{2}{*}{ Picual } & \multirow{2}{*}{ Manzanillo } & \multirow{2}{*}{ Mean } \\
\hline & & & & & & & & & \\
\hline Control & $39.00 \mathrm{ef}$ & $36.67 \mathrm{~g}$ & $37.83 \mathrm{E}$ & $10.67 \mathrm{~g}$ & $12.33 \mathrm{ef}$ & $11.50 \mathrm{E}$ & $57.06 \mathrm{a}$ & $49.75 b$ & $53.41 \mathrm{~A}$ \\
\hline $\begin{array}{l}\text { Foliar spray of mono-potassium phosphate } 0.3 \% \text { in } 1 \text { st } \\
\text { February }\end{array}$ & $40.00 \mathrm{e}$ & $38.00 \mathrm{fg}$ & $39.00 \mathrm{D}$ & $11.33 \mathrm{fg}$ & $13.67 \mathrm{de}$ & $12.50 \mathrm{D}$ & $55.92 \mathrm{a}$ & $47.18 \mathrm{c}$ & $51.55 \mathrm{~B}$ \\
\hline $\begin{array}{l}\text { Foliar spray of mono-potassium phosphate } 0.3 \% \text { in } 1 \text { st } \\
\text { February and hokley alpha before flowering }\end{array}$ & $44.67 \mathrm{c}$ & $42.33 d$ & $43.50 \mathrm{C}$ & $14.33 \mathrm{~d}$ & $17.33 \mathrm{c}$ & $15.83 \mathrm{C}$ & $51.42 \mathrm{~b}$ & $41.94 \mathrm{f}$ & $46.68 \mathrm{C}$ \\
\hline $\begin{array}{l}\text { Foliar spray of mono-potassium phospate } 0.3 \% \text { in } 1 \text { st } \\
\text { February and hokley alpha at } 40 \% \text { flowering }\end{array}$ & $48.00 \mathrm{~b}$ & $43.67 \mathrm{~cd}$ & $45.83 \mathrm{~B}$ & $17.67 \mathrm{~b}$ & $22.00 \mathrm{~b}$ & $19.83 \mathrm{~B}$ & $46.19 \mathrm{c}$ & $32.98 \mathrm{f}$ & $39.59 \mathrm{D}$ \\
\hline $\begin{array}{l}\text { Foliar spray of mono-potassium phosphate } 0.3 \% \text { in } 1 \text { st } \\
\text { February and hokley alpha before flowering }+40 \% \\
\text { flowering }\end{array}$ & $55.33 \mathrm{a}$ & $49.00 \mathrm{~b}$ & 51.17A & $20.67 b$ & $27.00 \mathrm{a}$ & $23.83 \mathrm{~A}$ & $44.14 \mathrm{~d}$ & $28.96 \mathrm{~g}$ & $36.55 \mathrm{E}$ \\
\hline \begin{tabular}{|l} 
Mean \\
\end{tabular} & $45.00 \mathrm{~A}$ & 41.93B & & 14.93B & $18.47 \mathrm{~A}$ & & $50.95 \mathrm{~A}$ & $40.16 \mathrm{~B}$ & \\
\hline
\end{tabular}

Means within each column or raw followed by the same letter (s) are not significantly different at $5 \%$ level. 
The production of Picual surpassed Manzanillo during 2012 season in the positive. Manzanillo gave the highest significant difference compared to Picual in 2013 season. The biennial bearing index was obvious of treatments.

Foliar application of MKP $0.3 \%$ on Feb. $1^{\text {st }}$ supplemented by Hokly alpha before flowering +40 $\%$ flowering on Manzanillo and Picual performed the highest significant difference compared to the control and other treatments. Meantime, the other treatments showed the intermediate values in yield. On the other hand, the control of Picual and Manzanillo gave the highest significant value of biennial bearing index compared to other treatments in descending order according to the treatment arrange.

Furthermore, all combinations of Picual treated with MKP and Hokly alpha enhanced yield and reduced biennial bearing compared to Manzanillo and other treatments during the two seasons of the experiment.

\section{Fruit characteristics}

Table (3) shows the effect of foliar application of monopotassium phosphate (MKP) $0.3 \%$ and Naphthalene acetic acid + Naphthalene acetamide (Hokly alpha) in the $1^{\text {st }}$ of February, before flowering and during $40 \%$ flowering on Manzanillo and Picual during 2012 and 2013 seasons. Concerning fruit weight (g.) and fruit shape index showed that Picual cv. gave the highest significant value compared to Manzanillo cv. as affected by MKP and Hokly alpha treatments in both seasons. In regard to fruit length and diameter the opposite was true with Manzanillo cv. which was superior compared to Picual cv. during the two growing seasons.

Concerning the effect of the treatments, although there weren't any significant difference of fruit weight, fruit length of Manzanillo and Picual in both seasons, beside fruit diameter and fruit shape index during 2013 only, fruit diameter was affected significantly with foliar application of MKP $0.3 \%$ and Hokly alpha at $40 \%$ flowering followed by other treatments. Meantime, foliar spray of MKP $0.3 \%$ in the $1^{\text {st }}$ of February and Hokly alpha before flowering $+40 \%$ flowering surpassed other treatments during 2012 only.

As for the combinations of the effect of the treatments and the two cultivars on fruit weight the foliar spray of MKP in the $1^{\text {st }}$ of February performed the highest significant value compared with other treatments. Foliar spray of MKP $0.3 \%$ in the $1^{\text {st }}$ of February and Hokly alpha before flowering $+40 \%$ flowering gave the highest significant values of fruit length in both seasons besides foliar spray of MKP in $1^{\text {st }}$ of February and Hokly alpha $40 \%$ flowering during 2013 season. All the treatments on Manzanillo cv. gave the superior values of fruit diameter without any significant differences between treatments compared to Picual in both seasons. On the other hand, Picual treatments surpassed
Manzanillo treatments regarding fruit shape index in both seasons without any significant difference between treatments in 2012 and 2013 seasons.

In regard to flesh weight and seed characteristics of Manzanillo and Picual in Table (4) as affected by aforementioned treatments. It is obvious that, Picual cv. Gave the highest significant values compared to Manzanillo in both 2012 and 2013 seasons. The effect of treatments showed that, the spray value compared to the other treatments during 2012 season, although in 2013 there weren't any significant difference of all treatments. As for the interaction of treatments and the two cultivars the control and the application of MKP $0.3 \%$ in the 1st of February and the control gave the highest significant values, meanwhile, the control only in 2013 gave the same analogous effect on Picual cv. only.

Concerning seed characteristics, the MKP at $0.3 \%$ in $1^{\text {st }}$ of February and Hokly alpha before flowering, MKP $0.3 \%$ in the 1st February and Hokly alpha at $40 \%$ flowering and MKP 0.3 in $1^{\text {st }}$ of February and Hokly alpha before flowering $+40 \%$ flowering surpassed other treatments in seed weight during 2012. However, foliar spray of MKP $0.3 \%$ in $1^{\text {st }}$ of February and Hokly alpha at $40 \%$ flowering gave analogous results during 2013 season. In regard to seed length there weren't any significant difference between treatments during 2012, while as foliar application of MKP $0.3 \%$ in the $1^{\text {st }}$ of February and Hokly alpha before flowering in addition to $40 \%$ flowering gave the highest significant value compared to the control and other treatments. Meantime, the MKP $0.3 \%$ in $1^{\text {st }}$ of February and Hoklyalpha before flowering and at $40 \%$ flowering gave the superior values of seed diameter 2012 and 2013 seasons, respectively.

Concerning the combination of treatments and cultivars, Picual cultivar treated with foliar application of MKP $0.3 \%$ in the $1^{\text {st }}$ February and Hokly alpha before flowering gave the highest significant value of seed weight in 2012 and MKP $0.3 \%$ in $1^{\text {st }}$ of February and Hokly alpha at $40 \%$ flowering during 2013 gave the same effect. As for seed length during 2013 all treatments surpassed on Picual without any significant difference, whereas, MKP $0.3 \%$ in $1^{\text {st }}$ of February and Hokly alpha before flowering in addition to $40 \%$ flowering gave the superior value during 2013, in regard the seed diameter MKP $0.3 \%$ in the $1^{\text {st }}$ of February and Hokly alpha at $40 \%$ flowering gave the highest values in both seasons.

\section{Fruit oil content.}

Table (5) shows the moisture $\%$, fresh oil (\%), dry oil (\%) and oil yield/tree (kg) Picula and Manzanillo cvs. as affected by monopotassium phosphate (MKP) and Naphthalene acetic acid and Naphthalene acetamide (Hokly alpha) before flowering and at $40 \%$ flowering during 2012 and 
2013 seasons, it is clear that, although there weren't any significant difference between two cultivars during 2013, Manzanillo cv. surpassed Picual during 2012 in moisture \%. While as, for oil as fresh and dry weight Picual cv. gave the highest significant values in both seasons, oil yield/tree (kg) of Picual surpassed Manzanillo during 2012 and the opposite cv. in yield of oil $(\mathrm{kg}) /$ tree.

Concerning the effect of treatments on moisture $\%$, although all treatments didn't perform any significant difference on both cultivars during 2013, MKP $0.3 \%$ in the $1^{\text {st }}$ of February and Hokly alpha before flowering treatment and the same treatment beside $40 \%$ flowering date gave the highest values during 2012. In regard to oil as fresh weight $\%$ all treatments didn't gave any significant difference in both seasons. Meantime, the foliar application of MKP $0.3 \%$ in $1^{\text {st }}$ of February treatment in addition to the Hokly alpha before flowering $+40 \%$ flowering gave the highest significant value of oil \% as dry weight. Meanwhile, MKP $0.3 \% 1^{\text {st }}$ of February and Hokly alpha before flowering during 2013 gave the superior value in oil \% as dry weight compared to the control and other treatments in 2013. The foliar spray of MKP $0.3 \%$ in $1^{\text {st }}$ of February + $40 \%$ flowering gave the highest significant values of oil yield/tree $(\mathrm{kg})$ in both seasons. In regard to the combination of the effect of treatments and cultivars the foliar application of MKP $0.3 \%$ in $1^{\text {st }}$ February and Hokly alpha before flowering $+40 \%$ flowering on Manzanillo cv. gave the highest values compared to Picual and other treatments in 2012, meantime the same treatment without $40 \%$ flowering application gave the same affect in 2013. As for the interaction of oil $\%$ as fresh weight the treatments didn't give any significant differences on both cultivars during the two growing seasons.

Concerning the oil \% as dry weight Picual in 2012 didn't take definite trend while, Manzanillo was highly affected by MKP 0.3 in the $1^{\text {st }}$ of flowering and Hokly alpha before flowering $+40 \%$ flowering. Meantime, during 2013 foliar spray of MKP $0.3 \%$ in $1^{\text {st }}$ of February and Hokly alpha before flowering on Manzanillo cv. surpassed Picual.

In regard to combinations of treatment and cultivars, the MKP $0.3 \%$ in the $1^{\text {st }}$ of February and Hokly alpha before flowering $+40 \%$ flowering surpassed other treatments on Manzanillo and Picual cvs. in both seasons.

\section{The Discussion}

The present data shows that, control trees of Picual and Manzanillo olive cvs. had the least fruit yield and the highest fruit drop percentage/meter. Accordingly, all the studied treatments have a positive effect and improved fruit set, yield, fruit characteristics and fruit oil content. Foliar spray of mono-potassium phosphate (MKP) $0.3 \%$ at $1^{\text {st }}$ February increased Picual fruit dimensions and its dry oil content. Foliar spray of MKP + Hokly Alpha (NAA + NAD) before flowering induced the highest fruit moisture of Picual (in the $1^{\text {st }}$ season) and Manzanillo olive cvs. (in the $2^{\text {nd }}$ season), the highest fresh oil content of Picual fruits (in 2013 season) as well as the highest dry oil content of Picual fruits (in 2012 season) and of Manzanillo cvs. (in 2013 season). The most effective treatment was the spray of MKP + Hokly Alpha before flowering and at $40 \%$ flowering. This treatment gave the highest percentage of fruit set and fruit yield. It increased number of fruits and retained fruits/meter as well as the highest oil yield/tree. Moreover, minimized fruit drop alleviate biennial bearing especially in Manzanillo more than Picual cv. Thus, we can recommend olive growers to apply this treatment to increase fruit set, yield and oil yield/tree subsequently increase their income.

Our results are in harmony with; former investigations of Toscano and Casacchia (2006) who reported that mono-potassium phosphate (MKP) improved olive flowering, fruit set, yield and oil quality may be as a result of improvement of nutritional status (Sarrwy et al., 2010) as foliar spray was considered as a fast source of $\mathrm{P}$ and $\mathrm{K}$ elements (Barranco et al., 2010).

Spray of naphthalene acetic acid (NAA) induced an adequate fruit thinning and increased profitability (Ebert and Kreuz, 1987) as well as improved apple fruit weight and size (Ebert, 1987). Also, using NAA shortly after full bloom is commonly practiced to decrease olive fruit thinning bud increase fruit size (Qureshi et al., 2012 and Barone et al., 2014).

Besides, Gomand and Goossens (2010) showed that, naphthalene acetamide (NAD) reduced apple fruit set while increased pomegranate fruit thinning, fruit, size and fruit shape index, may be as a result of improving root formation, root length and root weight (Bekaard $\boldsymbol{e t}$ al., 2005).

Thereupon, it is preferable to spray Picual and Manzanillo olive trees with mono-potassium phosphate at $0.3 \%$ on February, $1^{\text {st }}$ and Hokly alpha before blooming and again at $40 \%$ blooming to enhance tree fruiting and fruit quality. 
Table 3. Effect of mono potassium phosphate and Hokley alpha foliar spray on fruit properties of "Picual and Manzanillo" olive trees during 2012 and 2013 seasons.

\begin{tabular}{|c|c|c|c|c|c|c|c|c|c|c|c|c|}
\hline \multirow{2}{*}{\begin{tabular}{|l|} 
Cultivars \\
Treatments
\end{tabular}} & \multicolumn{3}{|c|}{ Fruit weight (g.) } & \multicolumn{3}{|c|}{ Fruit length } & \multicolumn{3}{|c|}{ Fruit diameter } & \multicolumn{3}{|c|}{ Fruit shape index } \\
\hline & Picual & Manzanillo & Mean & Picual & Manzanillo & Mean & Picual & Manzanillo & Mean & Picual & Manzanillo & Mean \\
\hline \multicolumn{13}{|c|}{ First season 2012} \\
\hline Control & $6.18 \mathrm{ab}$ & $5.28 \mathrm{~d}$ & $5.73 \mathrm{~A}$ & $2.80 \mathrm{ab}$ & $2.57 \mathrm{e}$ & $2.68 \mathrm{~A}$ & $1.94 b$ & $2.28 \mathrm{a}$ & $2.11 \mathrm{AB}$ & $1.44 \mathrm{a}$ & $1.13 c$ & $1.29 \mathrm{~B}$ \\
\hline $\begin{array}{l}\text { Foliar spray of mono-potassium phosphate } 0.3 \\
\% \text { in } 1^{\text {st }} \text { February }\end{array}$ & $6.21 \mathrm{a}$ & $5.32 \mathrm{~d}$ & $5.77 \mathrm{~A}$ & $2.82 \mathrm{ab}$ & $2.60 \mathrm{e}$ & $2.71 \mathrm{~A}$ & $1.95 \mathrm{~b}$ & $2.30 \mathrm{a}$ & $2.13 \mathrm{~A}$ & $1.44 \mathrm{a}$ & $1.13 \mathrm{c}$ & $1.29 \mathrm{~B}$ \\
\hline $\begin{array}{l}\text { Foliar spray of mono-potassium phosphate } 3 \% \\
\text { in } 1 \text { st February and hokley alpha before } \\
\text { flowering }\end{array}$ & $6.04 \mathrm{c}$ & $5.35 \mathrm{~d}$ & $5.70 \mathrm{~A}$ & $2.81 \mathrm{ab}$ & $2.67 \mathrm{c}-\mathrm{e}$ & $2.74 \mathrm{~A}$ & $1.89 \mathrm{~b}$ & $2.33 \mathrm{a}$ & $2.11 \mathrm{AB}$ & $1.49 \mathrm{a}$ & $1.15 \mathrm{bc}$ & $1.32 \mathrm{AB}$ \\
\hline $\begin{array}{l}\text { Foliar spray of mono-potassium phospate } 0.3 \% \\
\text { in } 1 \text { st February and hokley alpha at } 40 \% \\
\text { flowering }\end{array}$ & $6.11 b c$ & $5.28 \mathrm{~d}$ & $5.74 \mathrm{~A}$ & $2.74 b-d$ & $2.77 a-c$ & $2.76 \mathrm{~A}$ & $1.90 \mathrm{~b}$ & $2.35 \mathrm{a}$ & $2.12 \mathrm{~A}$ & $1.45 \mathrm{a}$ & $1.18 \mathrm{bc}$ & $1.31 \mathrm{AB}$ \\
\hline $\begin{array}{l}\text { Foliar spray of mono-potassium phosphate } 0.3 \\
\% \text { in } 1 \text { st February and hokley alpha before } \\
\text { flowering }+40 \% \text { flowering }\end{array}$ & $6.05 c$ & $5.36 \mathrm{~d}$ & $5.71 \mathrm{~A}$ & 2.64de & $2.88 \mathrm{a}$ & $2.76 \mathrm{~A}$ & $1.77 \mathrm{c}$ & $2.35 \mathrm{a}$ & $2.06 \mathrm{~B}$ & $1.49 \mathrm{a}$ & $1.22 \mathrm{~b}$ & $1.36 \mathrm{~A}$ \\
\hline \begin{tabular}{|c|} 
Mean \\
\end{tabular} & $6.12 \mathrm{~A}$ & $5.34 \mathrm{~B}$ & & $2.76 \mathrm{~A}$ & $2.70 \mathrm{~B}$ & & $1.89 \mathrm{~B}$ & $2.32 \mathrm{~A}$ & & $1.46 \mathrm{~A}$ & $1.16 \mathrm{~B}$ & \\
\hline \multicolumn{13}{|c|}{ Second season 2013} \\
\hline Control & $6.57 \mathrm{a}$ & $5.58 \mathrm{c}$ & $6.08 \mathrm{~A}$ & $2.92 b-e$ & $2.95 \mathrm{a}-\mathrm{d}$ & $2.93 \mathrm{~A}$ & $1.96 \mathrm{~b}$ & $2.35 \mathrm{a}$ & $2.15 \mathrm{~A}$ & $1.49 \mathrm{a}$ & $1.26 \mathrm{~b}$ & $1.38 \mathrm{~A}$ \\
\hline $\begin{array}{l}\text { Foliar spray of mono-potassium phosphate } 0.3 \\
\% \text { in } 1^{\text {st }} \text { February }\end{array}$ & $6.57 \mathrm{a}$ & $5.60 \mathrm{c}$ & $6.09 \mathrm{~A}$ & 2.91c-e & 2.96a-d & $2.94 \mathrm{~A}$ & $1.98 \mathrm{~b}$ & $2.36 \mathrm{a}$ & $2.17 \mathrm{~A}$ & $1.47 \mathrm{a}$ & $1.25 \mathrm{~b}$ & $1.36 \mathrm{~A}$ \\
\hline $\begin{array}{l}\text { Foliar spray of mono-potassium phosphate } 0.3 \\
\% \text { in } 1^{\text {st }} \text { February and hokley alpha before } \\
\text { flowering }\end{array}$ & $6.50 \mathrm{ab}$ & $5.61 \mathrm{c}$ & $6.06 \mathrm{~A}$ & 2.90de & $2.99 \mathrm{a}-\mathrm{c}$ & $2.94 \mathrm{~A}$ & $1.90 \mathrm{bc}$ & $2.38 \mathrm{a}$ & $2.14 \mathrm{~A}$ & $1.52 \mathrm{a}$ & $1.25 \mathrm{~b}$ & $1.39 \mathrm{~A}$ \\
\hline $\begin{array}{l}\text { Foliar spray of mono-potassium phospate } 0.3 \% \\
\text { in } 1 \text { st February and hokley alpha at } 40 \% \\
\text { flowering }\end{array}$ & $6.46 b$ & $5.59 \mathrm{c}$ & $6.02 \mathrm{~A}$ & $2.85 \mathrm{ef}$ & $3.00 \mathrm{a}$ & $2.93 \mathrm{~A}$ & $1.92 \mathrm{bc}$ & $2.39 \mathrm{a}$ & $2.15 \mathrm{~A}$ & $1.48 \mathrm{a}$ & $1.26 \mathrm{~b}$ & $1.37 \mathrm{~A}$ \\
\hline $\begin{array}{l}\text { Foliar spray of mono-potassium phosphate } 0.3 \\
\% \text { in } 1 \text { st February and hokley alpha before } \\
\text { flowering }+40 \% \text { flowering }\end{array}$ & $6.48 \mathrm{ab}$ & $5.59 \mathrm{c}$ & $6.04 \mathrm{~A}$ & $2.80 \mathrm{f}$ & $3.00 \mathrm{a}$ & $2.90 \mathrm{~A}$ & $1.85 \mathrm{c}$ & $2.39 \mathrm{a}$ & $2.12 \mathrm{~A}$ & $1.51 \mathrm{a}$ & $1.25 \mathrm{~b}$ & $1.38 \mathrm{~A}$ \\
\hline Mean & $6.52 \mathrm{~A}$ & $5.60 \mathrm{~B}$ & & $2.88 \mathrm{~B}$ & $2.98 \mathrm{~A}$ & & $1.92 \mathrm{~B}$ & $2.38 \mathrm{~A}$ & & $1.50 \mathrm{~A}$ & $1.26 \mathrm{~B}$ & \\
\hline
\end{tabular}

Means within each column or raw followed by the same letter (s) are not significantly different at $5 \%$ level. 
Table 4. Effect of mono potassium phosphate and Hokley alpha foliar spray on flesh weight and seed properties of "Picual and Manzanillo" olive trees during 2012 and 2013 seasons.

\begin{tabular}{|c|c|c|c|c|c|c|c|c|c|c|c|c|}
\hline \multirow{2}{*}{ Cultivars } & \multicolumn{3}{|c|}{ Flesh weight (g.) } & \multicolumn{3}{|c|}{ Seed weight } & \multicolumn{3}{|c|}{ Seed length } & \multicolumn{3}{|c|}{ Seed diameter } \\
\hline & Picual & Manzanillo & Mean & Picual & Manzanillo & Mean & Picual & Manzanillo & Mean & Picual & Manzanillo & Mean \\
\hline \multicolumn{13}{|c|}{ First season 2012} \\
\hline Control & $5.10 \mathrm{a}$ & $4.52 \mathrm{~d}$ & $4.81 \mathrm{AB}$ & $1.080 \mathrm{~b}$ & $0.753 \mathrm{e}$ & $0.917 \mathrm{~B}$ & $1.57 \mathrm{a}$ & $1.35 b$ & $1.46 \mathrm{~A}$ & $1.000 \mathrm{ab}$ & $0.950 f$ & $0.975 \mathrm{C}$ \\
\hline $\begin{array}{l}\text { Foliar spray of mono-potassium phosphate } 0.3 \\
\% \text { in } 1^{\text {st }} \text { February }\end{array}$ & $5.16 \mathrm{a}$ & $4.56 \mathrm{~d}$ & $4.86 \mathrm{~A}$ & $1.050 \mathrm{c}$ & $0.757 \mathrm{e}$ & $0.903 \mathrm{C}$ & $1.58 \mathrm{a}$ & $1.36 \mathrm{~b}$ & $1.47 \mathrm{~A}$ & $0.997 \mathrm{bc}$ & $0.960 \mathrm{ef}$ & $0.978 \mathrm{BC}$ \\
\hline $\begin{array}{l}\text { Foliar spray of mono-potassium phosphate } 3 \% \\
\text { in } 1 \text { st February and hokley alpha before } \\
\text { flowering }\end{array}$ & $4.93 \mathrm{c}$ & $4.59 \mathrm{~d}$ & $4.76 \mathrm{~B}$ & $1.107 \mathrm{a}$ & $0.767 \mathrm{e}$ & $0.937 \mathrm{~A}$ & $1.61 \mathrm{a}$ & $1.38 \mathrm{~b}$ & $1.50 \mathrm{~A}$ & $1.010 \mathrm{ab}$ & $0.980 \mathrm{~cd}$ & $0.995 \mathrm{~A}$ \\
\hline $\begin{array}{l}\text { Foliar spray of mono-potassium phospate } 0.3 \% \\
\text { in } 1^{\text {st }} \text { February and hokley alpha at } 40 \% \\
\text { flowering }\end{array}$ & $5.02 b$ & $4.58 \mathrm{~d}$ & $4.80 \mathrm{~B}$ & $1.093 \mathrm{ab}$ & $0.797 \mathrm{~d}$ & $0.945 \mathrm{~A}$ & $1.59 \mathrm{a}$ & $1.37 \mathrm{~b}$ & $1.48 \mathrm{~A}$ & $1.017 \mathrm{a}$ & $0.977 \mathrm{de}$ & 0.997A \\
\hline $\begin{array}{l}\text { Foliar spray of mono-potassium phosphate } 0.3 \\
\% \text { in } 1 \text { st February and hokley alpha before } \\
\text { flowering }+40 \% \text { flowering }\end{array}$ & $4.97 \mathrm{bc}$ & $4.55 \mathrm{~d}$ & $4.76 \mathrm{~B}$ & $1.080 \mathrm{~b}$ & $0.810 \mathrm{~d}$ & $0.945 \mathrm{~A}$ & $1.61 \mathrm{a}$ & $1.37 \mathrm{~b}$ & $1.49 \mathrm{~A}$ & $1.010 \mathrm{ab}$ & $0.970 \mathrm{de}$ & $0.990 \mathrm{AB}$ \\
\hline Mean & $5.04 \mathrm{~A}$ & $4.56 \mathrm{~B}$ & & $1.082 \mathrm{~A}$ & $0.777 \mathrm{~B}$ & & $1.59 \mathrm{~A}$ & $1.37 \mathrm{~B}$ & & $1.007 \mathrm{~A}$ & $0.967 \mathrm{~B}$ & \\
\hline \multicolumn{13}{|c|}{ Second season 2013} \\
\hline Control & $5.46 \mathrm{a}$ & $4.82 \mathrm{c}$ & $5.14 \mathrm{~A}$ & $1.113 b$ & $0.767 \mathrm{de}$ & $0.940 \mathrm{C}$ & $1.57 \mathrm{~b}$ & $1.38 \mathrm{c}$ & $1.47 \mathrm{~B}$ & $1.017 \mathrm{ab}$ & $0.963 \mathrm{~cd}$ & $0.990 \mathrm{BC}$ \\
\hline $\begin{array}{l}\text { Foliar spray of mono-potassium phosphate } 0.3 \\
\% \text { in } 1^{\text {st }} \text { February }\end{array}$ & $5.43 \mathrm{ab}$ & $4.83 \mathrm{c}$ & $5.13 \mathrm{~A}$ & $1.143 \mathrm{a}$ & $0.776 \mathrm{c}-\mathrm{e}$ & $0.960 \mathrm{AB}$ & $1.40 \mathrm{c}$ & $1.37 \mathrm{c}$ & $1.38 \mathrm{C}$ & $1.007 \mathrm{~b}$ & $0.953 \mathrm{~d}$ & $0.980 \mathrm{C}$ \\
\hline $\begin{array}{l}\text { Foliar spray of mono-potassium phosphate } 0.3 \\
\% \text { in } 1^{\text {st }} \text { February and hokley alpha before } \\
\text { flowering }\end{array}$ & $5.37 \mathrm{ab}$ & $4.85 \mathrm{c}$ & $5.11 \mathrm{~A}$ & $1.127 \mathrm{ab}$ & $0.763 \mathrm{e}$ & $0.945 \mathrm{BC}$ & $1.63 \mathrm{a}$ & $1.40 \mathrm{c}$ & $1.52 \mathrm{~A}$ & $1.007 \mathrm{~b}$ & $0.973 \mathrm{c}$ & $0.990 \mathrm{BC}$ \\
\hline $\begin{array}{l}\text { Foliar spray of mono-potassium phospate } 0.3 \% \\
\text { in } 1^{\text {st }} \text { February and hokley alpha at } 40 \% \\
\text { flowering }\end{array}$ & $5.31 b$ & $4.80 \mathrm{c}$ & $5.06 \mathrm{~A}$ & $1.143 \mathrm{a}$ & $0.787 \mathrm{~cd}$ & $0.965 \mathrm{~A}$ & $1.61 \mathrm{ab}$ & $1.40 \mathrm{c}$ & $1.50 \mathrm{AB}$ & $1.033 \mathrm{a}$ & $0.973 \mathrm{c}$ & $1.003 \mathrm{~A}$ \\
\hline $\begin{array}{l}\text { Foliar spray of mono-potassium phosphate } 0.3 \\
\% \text { in } 1 \text { st February and hokley alpha before } \\
\text { flowering }+40 \% \text { flowering }\end{array}$ & $5.36 \mathrm{ab}$ & $4.80 \mathrm{c}$ & $5.08 \mathrm{~A}$ & $1.117 \mathrm{~b}$ & $0.797 \mathrm{c}$ & $0.957 \mathrm{AB}$ & $1.63 \mathrm{a}$ & $1.41 \mathrm{c}$ & $1.52 \mathrm{~A}$ & $1.020 \mathrm{ab}$ & $0.970 \mathrm{~cd}$ & $0.995 \mathrm{AB}$ \\
\hline Mean & $5.39 \mathrm{~A}$ & $4.82 \mathrm{~B}$ & & $1.129 \mathrm{~A}$ & $0.778 \mathrm{~B}$ & & $1.57 \mathrm{~A}$ & $1.39 \mathrm{~B}$ & & $1.017 \mathrm{~A}$ & $0.967 \mathrm{~B}$ & \\
\hline
\end{tabular}

Means within each column or raw followed by the same letter (s) are not significantly different at $5 \%$ level. 
Table 5. Effect of mono potassium phosphate and Hokley alpha foliar spray on fruit, moisture content (\%), oil content (\%) and yield of "Picual and Manzanillo" olive trees during 2012 and 2013 seasons.

\begin{tabular}{|c|c|c|c|c|c|c|c|c|c|c|c|c|}
\hline \multirow[b]{2}{*}{ Cultivars } & \multicolumn{3}{|c|}{ Moisture (\%) } & \multicolumn{3}{|c|}{ Fresh oil $(\%)$} & \multicolumn{3}{|c|}{ Dry oil $(\%)$} & \multicolumn{3}{|c|}{ Oil yield/tree $(\mathrm{kg})$} \\
\hline & \multirow{2}{*}{ Picual } & \multirow{2}{*}{ Manzanillo } & \multirow{2}{*}{ Mean } & \multirow{2}{*}{ Picual } & \multirow{2}{*}{ Manzanillo } & \multirow{2}{*}{ Mean } & \multirow{2}{*}{ Picual } & \multirow{2}{*}{ Manzanillo } & \multirow{2}{*}{ Mean } & \multirow{2}{*}{ Picual } & \multirow{2}{*}{ Manzanillo } & \multirow{2}{*}{ Mean } \\
\hline Treatments & & & & & & & & & & & & \\
\hline \multicolumn{13}{|c|}{ First season 2012} \\
\hline Control & $63.76 \mathrm{~cd}$ & $65.39 \mathrm{a}-\mathrm{c}$ & $64.57 \mathrm{AB}$ & $19.00 \mathrm{a}$ & $17.37 \mathrm{~b}$ & $18.19 \mathrm{~A}$ & $52.43 \mathrm{ab}$ & $50.23 c$ & $51.33 \mathrm{~B}$ & $7.41 d$ & $6.37 \mathrm{e}$ & $6.89 \mathrm{D}$ \\
\hline $\begin{array}{l}\text { Foliar spray of mono-potassium } \\
\text { phosphate } 0.3 \% \text { in } 1 \text { st February }\end{array}$ & $\begin{array}{l}64.25 b- \\
d\end{array}$ & $63.03 \mathrm{~d}$ & 63.64B & $18.94 \mathrm{a}$ & $17.57 b$ & $18.26 \mathrm{~A}$ & $53.03 \mathrm{ab}$ & $52.29 \mathrm{ab}$ & $52.66 \mathrm{~A}$ & $7.58 \mathrm{~d}$ & $6.68 \mathrm{e}$ & 7.13D \\
\hline $\begin{array}{l}\text { Foliar spray of mono-potassium } \\
\text { phosphate } 0.3 \% \text { in } 1 \text { st February } \\
\text { and hokley alpha before flowering }\end{array}$ & $\begin{array}{l}64.60 b- \\
d\end{array}$ & $65.77 \mathrm{ab}$ & $65.19 \mathrm{~A}$ & $18.77 \mathrm{a}$ & $17.52 b$ & $18.15 \mathrm{~A}$ & $53.03 \mathrm{ab}$ & $51.20 \mathrm{bc}$ & $52.11 \mathrm{AB}$ & $8.38 \mathrm{c}$ & $7.40 \mathrm{~d}$ & $7.90 \mathrm{C}$ \\
\hline $\begin{array}{l}\text { Foliar spray of mono-potassium } \\
\text { phospate } 0.3 \% \text { in } 1 \text { st February and } \\
\text { hokley alpha at } 40 \% \text { flowering }\end{array}$ & $\begin{array}{c}64.15 b- \\
d\end{array}$ & $65.15 a-c$ & $64.65 \mathrm{AB}$ & $18.81 \mathrm{a}$ & $17.45 b$ & $18.13 \mathrm{~A}$ & $52.50 \mathrm{ab}$ & $50.10 \mathrm{c}$ & $51.30 \mathrm{~B}$ & $9.02 b$ & $7.62 d$ & $8.32 \mathrm{~B}$ \\
\hline $\begin{array}{l}\text { Foliar spray of mono-potassium } \\
\text { phosphate } 0.3 \% \text { in } 1 \text { st February } \\
\text { and hokley alpha before flowering } \\
+40 \% \text { flowering }\end{array}$ & $\begin{array}{c}63.99 b- \\
d\end{array}$ & $66.54 \mathrm{a}$ & $65.26 \mathrm{~A}$ & $18.87 \mathrm{a}$ & $18.03 \mathrm{ab}$ & $18.45 \mathrm{~A}$ & $52.43 \mathrm{ab}$ & $53.88 \mathrm{a}$ & $53.15 \mathrm{~A}$ & $10.06 \mathrm{a}$ & $8.83 b c$ & $9.45 \mathrm{~A}$ \\
\hline Mean & $64.15 B$ & $65.18 \mathrm{~A}$ & & $18.88 \mathrm{~A}$ & $17.59 \mathrm{~B}$ & & $52.69 \mathrm{~A}$ & $51.54 \mathrm{~B}$ & & $8.49 \mathrm{~A}$ & $7.38 \mathrm{~B}$ & \\
\hline \multicolumn{13}{|c|}{ Second season 2013} \\
\hline Control & $64.78 b$ & $65.59 \mathrm{ab}$ & $65.19 \mathrm{~A}$ & $18.43 \mathrm{a}$ & $17.59 \mathrm{a}$ & $18.01 \mathrm{~A}$ & $52.35 \mathrm{c}$ & $51.32 b$ & $51.83 \mathrm{~B}$ & $1.96 \mathrm{~g}$ & $2.17 \mathrm{fg}$ & 2.07D \\
\hline $\begin{array}{l}\text { Foliar spray of mono-potassium } \\
\text { phosphate } 0.3 \% \text { in } 1 \text { st February }\end{array}$ & $64.46 b$ & $65.75 \mathrm{ab}$ & $65.10 \mathrm{~A}$ & $18.43 \mathrm{a}$ & $17.53 \mathrm{a}$ & $17.98 \mathrm{~A}$ & $51.86 \mathrm{~d}$ & $51.32 \mathrm{bc}$ & $51.54 \mathrm{~B}$ & $2.88 \mathrm{fg}$ & $2.40 \mathrm{ef}$ & $2.24 \mathrm{D}$ \\
\hline $\begin{array}{l}\text { Foliar spray of mono-potassium } \\
\text { phosphate } 0.3 \% \text { in } 1 \text { st February } \\
\text { and hokley alpha before flowering }\end{array}$ & $64.55 b$ & $66.84 \mathrm{a}$ & $65.69 \mathrm{~A}$ & $18.86 \mathrm{a}$ & $17.52 \mathrm{a}$ & $18.19 \mathrm{~A}$ & $53.20 \mathrm{~b}$ & $54.30 \mathrm{a}$ & $53.75 \mathrm{~A}$ & 2.70de & $3.04 \mathrm{~cd}$ & $2.87 \mathrm{C}$ \\
\hline $\begin{array}{l}\text { Foliar spray of mono-potassium } \\
\text { phospate } 0.3 \% \text { in } 1 \text { st February and } \\
\text { hokley alpha at } 40 \% \text { flowering }\end{array}$ & $64.87 \mathrm{~b}$ & $65.43 \mathrm{ab}$ & $65.15 \mathrm{~A}$ & $18.80 \mathrm{a}$ & $17.54 \mathrm{a}$ & $18.17 \mathrm{~A}$ & $53.55 b$ & $50.80 \mathrm{~cd}$ & $52.17 \mathrm{~B}$ & $3.32 \mathrm{c}$ & $3.86 \mathrm{~b}$ & $3.59 \mathrm{~B}$ \\
\hline $\begin{array}{l}\text { Foliar spray of mono-potassium } \\
\text { phosphate } 0.3 \% \text { in } 1 \text { st February } \\
\text { and hokley alpha before flowering } \\
+40 \% \text { flowering }\end{array}$ & $65.74 \mathrm{ab}$ & $65.26 \mathrm{ab}$ & $65.50 \mathrm{~A}$ & $18.54 \mathrm{a}$ & $17.63 \mathrm{a}$ & $18.08 \mathrm{~A}$ & $54.21 \mathrm{a}$ & $50.74 d$ & $52.48 \mathrm{~B}$ & $3.83 b$ & $4.76 \mathrm{a}$ & $4.30 \mathrm{~A}$ \\
\hline Mean & $64.88 \mathrm{~A}$ & $65.77 \mathrm{~A}$ & & $18.61 \mathrm{~A}$ & $17.56 \mathrm{~A}$ & & $53.03 \mathrm{~A}$ & $51.68 \mathrm{~B}$ & & $2.78 \mathrm{~B}$ & $3.24 \mathrm{~A}$ & \\
\hline
\end{tabular}

Means within each column or raw followed by the same letter (s) are not significantly different at $5 \%$ level. 


\section{References}

Abdolla K, M., M. A. Melegi, A. H. Hussein and T. A. Ahmed (1986). Mineral aspects of floral development in citrus changes in ovarian Nitrogen , Potassium and Phosphorous. Acta.Hort 175:199-207.

A.O.A.C. Association of Official Agricultural Chemists (1990). "Official Methods of Analysis" Benjamin Franklin Station, Washington, D.C. USA. P. 495-510.

Arquero, O.; Navarro, C.; Barranco, D. and Toro C. (2002). Use of mono-potassium phosphate as leaf fertilizer in the olive. Acta. Hort. 586: 409-410.

Bar Akiwa, A. V., Hiller and J. Pratt (1988). Effect of phosphorous and chicken manure on yield fruit quality, and leaf composition of grapefruit trees. Proc. of Amer. Soc. Hort. Sci. 93:145-152.

Barone, E.; Mantia, M.; LaMarchese A. and Marra, F. P. (2014). Improvement in yield and fruit size and quality of table olive cvs. Scienta Agricola, 71 (1): 52-57.

Barranco, D.; Ercan, H.; Munoz, C.; Beloj, A. and Arquero, O. (2010). Factors influence the efficiency of foliar sprays of mono-potassium phosphate in the olive. Inter. J. Plant Prod. 4 (3): 235-240

Bekaardt, C. R.; Pieterse, P. J.; Remten, E. Y. And Agenbag, G. (2005). Rooting responses of guayule cutting to hormone solutions. South African J. Plant and Soil. 22 (4): 266-268.

Birger, R.; Abd-El-Hadi, F.; Ronen, A.; Cohe, E.; Ankorion, Y. and Najjar, A. (2008). Increasing fruit size in table-olives. Acta Hort., 791 (1): 249255.

Comai, M. and Dorigoni, A. (1998). Comparison of treatments for incisive thinning of Golden Delicious. Informatore Agrario 54 (16): 73-80.

Dag, A. B.; A. Avni; A. Lavee and Riov, S. (2009). Fruit thinning using NAA shows potential for reducing biennial bearing of oil olive trees. Crop \& Pasture Sci., 60 (12): 1124-1130.

Duncan, D. B. (1955). Multiple range and multiple F. tests. Biometrics, 11: 1-42.

Ebert, A. (1987). Effect of an addition of mineral oil on chemical thinning of apples. Erwer, 29: 84-87 (Hort. Abst., 57: 5278).

Ebert, A. and C. L., Kreuz (1987). Chemical thinning of "Gala" apple. Scientia Hort., 36 229-240.

El-Sayed, M. E. and Saad El-Din, I. (2011). Modern technique in planting and production of olive. A pamphlet publication, Hort. Res. Inst., Giza, Egypt.
Gomand, A. and Gossens, H. (2010). Optimization of chemical pruning in apple. Fruitteelt-nieuws; 23 (7): 9-8.

Honeyboren, G. E. (1993). Chemical thinning of apple with Promalin and NAD. Decidous Fruit Grower, 43 (10): 375-379.

Maltoni, M. L. (1992). The use of GA4+7 and NAA or NAD to improve apple quality. Informatore Agrario, 48 (16): 79-86.

Qureshi, F. F. K.; Khan, A.; Hassan, F. and Nabila Bibi (2012). Effect of girdling and plant growth regulators on productivity in olive. Pakistan J. Agric. Res., 25 (2): 120-128.

Rahemi, A. and Atahasseini, A. (2004). Effect of plant growth regulators on fruit characteristics and leaf area of pomegranate. Acta Hort., 662: 313-317.

Sarrwy, S. M.A; Mohamed, E. A. and Hassan, H. S. A. (2010). Effect of foliar sprays with potassium nitrate and mono-potassium phosphate on leaf mineral content, fruit set, yield and fruit quality of Picual olive trees. Amer-Eurasian J. Agric. And Envir., Sci., 8 (4): 420-430.

Sibbett, G. S. and Ferguson, L. (2002). Nitrogen, boron and potassium dynamics in "On" vs. "Off" cropped Manzanillo olive trees in California, USA. Acta Hort., 586: 369-373.

Snedecor, G. W. and W.G Cochran (1980). Statistical methods. $7^{\text {th }}$ ed. Iowa. State Univ. Press, Ames, Iowa, USA pp. 507.

Taghipour, L.; Rahemi, M. and Assa, P. (2011). Thinning with NAA, NAD, ethephon, urea and by hand to improve fruit quality of apricot. Brazilian J. Plant phys.; 23 (4): 279-284.

Toscano, P. and Casacchia, T. (2006) A growth regulator to facilitate mechanical harvesting in olives. Informatore Agrario; 62 (38): 61-63.

Wilcox, J. C. (1944). Some factors affecting apple yield in the Okanagan Valley. Sci. Agric. 25: 189-213. 


\section{تأثير مادتى من المنشطات على إثمار وصفات جودة ثمار صنفى الزيتون البيكوال والمنزانيللو عماد جرجس ميخائيل وكمال جرجس جورجيوس قسم بحوث الزيتون وفاكهة المناطق شبه الجافة- معهد بحوث البساتين - مركز البحوث الزراعية - الجيزة}

أجريت هذه التجربة على أثجار الزيتون صنفى بيكوال ومنزانيللو عمرها 9 سنوات لدراسة تأثثر ش الأشجار بـ 3 \% فوسفات أحادى البوتاسيوم (MKP) فى

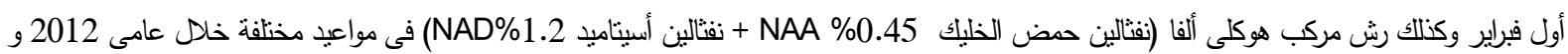

لوحظ أن كل المعاملات تحت الدراسة حسنت عقد الثثار والمحصول وصفات الثمار ومحتوى زيت الزيتون عن أثنجار المقارنة. وكانت أفضل المعاملات هى رش الأشجار بمركب MKP + مركب هوكلى ألفا (نفالين حض الخليك NAA + نفالين أسيتاميد NAD) قبل التزهير ثم عند 40 \% تزهير . هذه المعاملة نمكن مزراعى الزيتون من زيادة نسبة عقد الثمار والمحصول ومواصفات الثمرة ومحصول الزبت بالإضافة إلى تقليل نبادل الحمل وبالتالى زيادة الدخل. 